Kong. Res. J. 1(2): 72-79, 2014

Kongunadu Arts and Science College, Coimbatore

\title{
PHYSICO-CHEMICAL CHARACTERISTICS OF THE PONDS CHERUKULANGARA AND ARYANAMBI IN
} KERALA

\author{
Jipsa, J.R*, K.K. Mohammed Anwar and S. Logaswamy \\ Department of Zoology, Kongunadu Arts and Science College, Coimbatore -641029. \\ *E.mail: jipsaaa@gmail.com
}

\section{ABSTRACTS}

The quality of water is identified in terms of its physical, chemical and biological parameters. Limnological features of two such temple ponds, the Cherukulangara temple pond and Aryanambi temple pond were undertaken in the present study. The biological parameters of the ponds were also made during the study. In the present investigation all the parameters showed higher values in Pond B compared to Pond A. All values are found to be within or less than the permissible limit. Both ponds showed an oligotrophic nature with the presence of poor nutrients and low vegetation. Both ponds are unpolluted fresh water bodies which have no chemical or sewage pollution. It is suggested that the higher authorities should take steps to maintain the quality of fresh water bodies including ponds from all kinds of pollution and balance the fresh water ecosystem.

Keywords: Pollution,Cherukulangara temple pond,Aryanambi temple pond,Water quality and Air.

\section{INTRODUCTION}

Water also performs unique and indispensible activities in earth ecosystem, biosphere and biogeochemical cycles.Approximately $70 \%$ of the water in India has become polluted due to the discharge of domestic sewage and industrial effluents into natural water source, such as rivers, streams as well as lakes (Sangu and Sharma,1987).

The quality of water is described by its physical, chemical and biological characteristics. But if, some correlations were possible among these parameters, then significant ones would be fairly useful to indicate the quality of water (Dhembare et al., 1997). The deterioration of quality, loss of biodiversity and fast depletion of water resources are the main challenges, which need urgent attention.A pond is an earthern container for storing water. A pond os a dynamic and ever-changing community of plants and animals.

\section{MATERIALS AND METHODS}

The study of Cherukulangara temple was in the Palakkad district in Kerala. is situated near rice field and agricultural land, Thrichur in Kerala. The pond is used for bathing and it is a main source for the irrigation purposes during summer season. The Aryanambi temple pond is situated in Palakkad., Kerala. There are four bathing ghats in the pond.The study was conducted during the period from November to February (2012-2013) by which temperature range was in between $25^{\circ} \mathrm{C}$ and $19^{\circ} \mathrm{C}$ and the rainfall is about 3.5 to $2111.4 \mathrm{~mm}$. The analysis of all parameters like "total solids, dissolved oxygen, free carbon dioxide, carbonate, bicarbonate, calcium, magnesium, chloride, sulphate, phosphate, nitrate, iron, silicate and biological oxygen demand were estimated in the laboratory following the standard methods of APHA (2005).Qualitative analysis of plankton and fishes were also made in both the ponds A and B. Plankton were studied under compound microscope and identified with the help of standard references (Adoni et al., 1985; Agarker et al., 1994).

\section{RESULTS AND DISCUSSION}

During experimental period (November 2012 to February 2013), the environmental temperature ranged between $25^{\circ} \mathrm{C}$ and $32^{\circ} \mathrm{C}$ in pond $\mathrm{A}$ and in pond $\mathrm{B}$, it was between $26^{\circ} \mathrm{C}$ and $33^{\circ} \mathrm{C}$ in pond $\mathrm{B}$.The highest air and water temperature value $\left(33^{\circ} \mathrm{C}\right.$ and $\left.25^{\circ} \mathrm{C}\right)$ was recorded in February in pond $\mathrm{B}$ and the lowest air and water temperature value $\left(25^{\circ} \mathrm{C}\right.$ and $\left.19^{\circ} \mathrm{C}\right)$ was recorded in pond $\mathrm{A}$ in December. The water temperature was consistently lower than the atmospheric temperature. Similarly the bottom water temperature was consistently lower than the surface water.

$\mathrm{pH}$ values varied between 6.33 to8.0 in both $\mathrm{A}$ and $\mathrm{B}$ ponds. The maximum $\mathrm{pH}$ value was recorded $8.0 \pm 0$ in Pond $\mathrm{B}$ during December and minimum value was recorded $6.33 \pm 0.29$ in Pond $A$ during November.In the present investigation the $\mathrm{pH}$ values were maximum during December and minimum during November. Besides the Pond $\mathrm{B}$ showing high $\mathrm{pH}$ value by comparing with Pond $\mathrm{A}$, while both ponds keeping same variation of $\mathrm{pH}$ from slightly acidic to slightly alkali during November to February. 
Maximum value of total solids was observed in Pond $\mathrm{B}(2333.33 \pm 288.67 \mathrm{mg} / \mathrm{L})$ and minimum value was observed in Pond $A(833.33 \pm 288.67 \mathrm{mg} / \mathrm{L})$. Based on the seasonal variation it was observed that the maximum value was found during November and ranged from $1833.33 \mathrm{mg} / \mathrm{L}$ to $2333.33 \mathrm{mg} / \mathrm{L}$ and minimum value was observed during January and ranged from 833.33 to $1500 \mathrm{mg} / \mathrm{L}$.From these two Ponds Pond A showed high TS content than Pond B.In both the ponds, bottom water showed high TS content than surface water.

Dissolved oxygen (DO) values ranged from $3.66 \mathrm{mg} / \mathrm{L}$ to $6.34 \mathrm{mg} / \mathrm{L}$ of which maximum value $(6.34 \pm 0.28 \mathrm{mg} / \mathrm{L})$ was noted in Pond A during December and minimum value $(3.66 \pm 0.05 \mathrm{mg} / \mathrm{L})$ in Pond B during February. Seasonally it is observed that DO values was more in December followed by January, November and less value was found in February in both the ponds. From these two ponds Pond A showed high oxygen level than Pond B.In both the ponds,surface water showed high oxygen level than bottom water.

Free Carbon dioxide is also one of the most important factors in aquatic habitat. It is highly soluble in water and is the main source of carbon path way in the nature. Plant absorbs the free carbon dioxide present in both atmosphere and water. Carbon dioxide in water bodies is contributed by the respiratory activity of the animals (Vasumathy et al.,2009). Free carbon dioxide in the present study varied from an average of $2.75 \mathrm{mg} / \mathrm{L}$ to $14.41 \mathrm{mg} / \mathrm{L}$. The lowest value $(2.75 \pm 0.421 \mathrm{mg} / \mathrm{L})$ of free carbon dioxide was recorded in the surface water of Pond A in December month (winter season) where as the highest value (14.41 $\pm 0.751 \mathrm{mg} / \mathrm{L})$ was observed in the bottom water of Pond B during the period of January (pre summer season). Pond B showed consistently higher carbon dioxide than that of Pond A. Similarly the bottom water showed higher carbon dioxide than surface water. Seasonally carbon dioxide was more in January followed by November,January and less value was found in December in both ponds.

Carbonate is an important parameter which contributes to alkalinity. But in the present study, the bicarbonate was found to be absent. Bicarbonate is an important parameter which contributes to alkalinity.Value was varied from an average of 0 to $23.33 \mathrm{mg} / \mathrm{L}$ of which maximum value $23.33 \pm$ $2.886 \mathrm{mg} / \mathrm{L}$ )was observed in bottom water of Pond B during February,2013(pre summer season).During December,2012 (winter season)the bicarbonate was totally absent in Pond A.
Calcium was found higher $(28.33 \pm 2.886$ $\mathrm{mg} / \mathrm{L}$ ) in the bottom water of Pond B in January and lower $(8.33 \pm 2.886 \mathrm{mg} / \mathrm{L})$ in the surface water of Pond $\mathrm{A}$ in November. The calcium value was fluctuated from an average of 11.66 to $28.33 \mathrm{mg} / \mathrm{L}$ in Pond $\mathrm{B}$ and is higher when it is compared with Pond A. Seasonally calcium was more in January followed by October, December and less value was found in November in both ponds. The presence of calcium in the bottom water was consistently higher than the surface water in both ponds.

Salts of magnesium are found dissolved in all water. Rocks are the main source of magnesium. It is needed by all animals for phosphate transfer involving ATP and ADP. Magnesium was found maximum $(23.33 \pm 2.886 \mathrm{mg} / \mathrm{L})$ in the deeper part of Pond B in November and minimum $(3.33 \pm 2.886)$ in the surface water of Pond A in January. The magnesium value was fluctuated from an average of $8.33 \pm 2.886 \mathrm{mg} / \mathrm{L}$ to $21.66 \pm 5.773 \mathrm{mg} / \mathrm{L}$ in Pond B is higher when it is compared with Pond A. The magnesium level in the deeper water was consistently higher than that of surface water.

The ecological significance of chloride lies in its potential to regulate salinity of water and exert consequent osmotic stress on biotic communities (Shinde et al., 2001). Chloride showed high significant positive relationship with water temperature, bicarbonate and calcium. The chloride content in studied ponds varied from an average of 28.4 to $68.63 \mathrm{mg} / \mathrm{L}$ in Pond A, while in the Pond B its contents ranged from 35.5 to $85.2 \mathrm{mg} / \mathrm{L}$ respectively. The chloride content was lower than the maximum permissible limit prescribed by WHO standards (1993). It was observed that Pond B having more chloride content than Pond A, where as the bottom water having high chloride content than the surface water in both ponds during the study period. Seasonally, chloride was more in February followed by November, January and less value was found in December in both ponds.

Sulphate level was maximum $(98.16 \pm 1.44$ $\mathrm{mg} / \mathrm{L}$ ) in November at the bottom water of Pond B, while the minimum value $(60.72 \pm 1.639 \mathrm{mg} / \mathrm{L})$ was observed in surface water of Pond A during pre summer season (February).Seasonally it can be said that sulphate was more in November followed by December, January and less value was found in February in both ponds. Pond B was leading in the amount of sulphate than Pond $\mathrm{A}$ in all seasons. Bottom water was observed consistently higher sulphate than surface water. The overall value was less than maximum permissible limits $(500 \mathrm{mg} / \mathrm{L}$ ) according to WHO standards (1993), indicating that 
the pond was free from sulphate pollution during the study periods.

Phosphate level was maximum $(0.84 \pm 0.15 \mathrm{mg} / \mathrm{L})$ was observed in the surface water of Pond A during February month(pre summer season). Seasonally it can be say that phosphate was more in November followed by December,January and less value was found during February in both ponds.Pond B recorded high amount of phosphate than Pond A in all seasons. Bottom water consistently higher phosphate than surface water.

Nitrate level was maximum $(37.54 \pm 0.88 \mathrm{mg} / \mathrm{L})$ in February at the bottom water of Pond $B$, while the minimum value $(18.80 \pm 1.20 \mathrm{mg} / \mathrm{L})$ in February at the surface water of Pond A.Nitrate values were more in November followed by December, January and less value was found in February in both ponds. From these two ponds Pond B showed high nitrogen level than Pond $A$ in all seasons. Similarly bottom water showed high nitrate level than surface water.

\section{REFERENCES}

Adoni, A., D.G. Joshi, K. Gosh, S.K. Chourasia, A.K. Vaishya, M. Yadav and H.G. Verma, (1985). Work book on limnology, Pratibha Publisher,Sagar 1-166.

Agarker, M.S., H.K. Goswami, S. Kaushik, S.M. Mishra, A.K. Bajpai, and U.S. Sharma, (1994).Biology, conservation and management of bhojwtland, upper lake ecosystem in Bhopal. Bionature. 14:250- 273.

APHA. (2005). Standard methods for the examination of water and waste waters, 21stEdn., Washington. DC. USA.

Dhembare, A.J. and G.M. Pondhe, (1997). Correlation of ground water parameters of Pravara area. Maharashtra state, India. 12, pp.32-33.

Pandey, Ushapandey Tyagi HR and N. Rai, (1998) Algal flora and physico-chemical environment of Fatehsaker lake. Phycos, 37(187): 29-30.

Sangu, R.P.S and S.Sharma, (1987). Ind. J. Ecol.14: 278.

Shinde, S.E., T.S. Pathan, K.S. Raut and D.L. Sonawane, (2001). Middle East J.of Sci. Research, 8(3): 544554.

Sukumaran, M, M. Brinth and M. Pillai, (2008). PH Species composition and diversity of phytoplankton of Pechparai dam. India. $J$ of Ther and Expl Bio. 4(4): 157-161.

Vasumathi Reddy, K., K. Laxmiprasad, M. Swamy, and T.J. Ravinder Reddy, (2009). Aqua Biol, 24(1): 1.

WHO, (1993). Guidelines for drinking water supply quantity (2nd edn), 1, Recommendations. World Health Organization, Geneva, 180-181. 
Table.1. Temperature of Cherukulangara temple pond during the study period Nov. 2012 - Feb. 2013.

\begin{tabular}{|c|c|c|c|c|c|c|c|c|c|c|c|c|}
\hline \multirow{3}{*}{ Parameters } & \multicolumn{3}{|c|}{ Nov.2012 } & \multicolumn{3}{|c|}{ Dec.2012 } & \multicolumn{3}{|c|}{ Jan.2013 } & \multicolumn{3}{|c|}{ Feb.2013 } \\
\hline & \multicolumn{3}{|c|}{$\begin{array}{c}\text { Cherukulangara } \\
\text { Temple pond }\end{array}$} & \multicolumn{3}{|c|}{$\begin{array}{c}\text { Cherukulangara } \\
\text { Temple pond }\end{array}$} & \multicolumn{2}{|c|}{ Cherukulangara } & temple pond & \multicolumn{3}{|c|}{ Cherukulangara temple pond } \\
\hline & Air & $\begin{array}{l}\text { Surface } \\
\text { Water }\end{array}$ & $\begin{array}{c}\text { Bottom } \\
\text { water }\end{array}$ & Air & $\begin{array}{l}\text { Surface } \\
\text { water }\end{array}$ & $\begin{array}{l}\text { Bottom } \\
\text { water }\end{array}$ & Air & $\begin{array}{c}\text { Surface } \\
\text { water }\end{array}$ & $\begin{array}{c}\text { Bottom } \\
\text { water }\end{array}$ & Air & $\begin{array}{l}\text { Surface } \\
\text { water }\end{array}$ & $\begin{array}{c}\text { Bottom } \\
\text { water }\end{array}$ \\
\hline $\begin{array}{c}\text { Temperature } \\
\left({ }^{\circ} \mathrm{C}\right)\end{array}$ & 28 & 21 & 19 & 25 & 19 & 17 & 26 & 20 & 18 & 32 & 24 & 22 \\
\hline
\end{tabular}

Table.2. Temperature of aryanambi temple pond during the study period Nov.2012-Feb.2013

\begin{tabular}{|c|c|c|c|c|c|c|c|c|c|c|c|c|}
\hline \multirow{2}{*}{ Parameters } & \multicolumn{3}{|c|}{$\begin{array}{c}\text { Nov.2012 } \\
\text { aryanambi temple pond }\end{array}$} & \multicolumn{3}{|c|}{$\begin{array}{c}\text { Dec. } 2012 \\
\text { Aryanambi temple pond }\end{array}$} & \multicolumn{3}{|c|}{$\begin{array}{c}\text { Jan.2013 } \\
\text { Aryanambi temple pond }\end{array}$} & \multicolumn{3}{|c|}{$\begin{array}{c}\text { Feb. } 2013 \\
\text { Aryanambi temple pond }\end{array}$} \\
\hline & Air & $\begin{array}{c}\text { Surface } \\
\text { Water }\end{array}$ & $\begin{array}{c}\text { Bottom } \\
\text { water }\end{array}$ & Air & $\begin{array}{c}\text { Surface } \\
\text { water }\end{array}$ & $\begin{array}{c}\text { Bottom } \\
\text { water }\end{array}$ & Air & $\begin{array}{c}\text { Surface } \\
\text { water }\end{array}$ & $\begin{array}{c}\text { Bottom } \\
\text { water }\end{array}$ & Air & $\begin{array}{c}\text { Surface } \\
\text { water }\end{array}$ & $\begin{array}{c}\text { Bottom } \\
\text { water }\end{array}$ \\
\hline $\begin{array}{l}\text { Temperature } \\
\left({ }^{\circ} \mathrm{C}\right)\end{array}$ & 29 & 22 & 20 & 26 & 20 & 18 & 27 & 21 & 19 & 33 & 25 & 23 \\
\hline
\end{tabular}

Table.3. Chemical parameters of Aryanambi temple pond during the study period Nov.2012-Feb.2013

\begin{tabular}{|c|c|c|c|c|c|c|c|c|}
\hline \multirow{3}{*}{ Parameters } & \multirow{2}{*}{\multicolumn{2}{|c|}{$\begin{array}{l}\text { Nov.2012 } \\
\text { Cherukulangara } \\
\text { Temple pond } \\
\end{array}$}} & \multirow{2}{*}{\multicolumn{2}{|c|}{$\begin{array}{l}\text { Dec.2012 } \\
\text { Cherukulangara } \\
\text { Temple pond }\end{array}$}} & \multicolumn{2}{|l|}{ Jan.2013 } & \multicolumn{2}{|l|}{ Feb.2013 } \\
\hline & & & & & \multicolumn{2}{|c|}{ Cherukulangara temple pond } & \multicolumn{2}{|c|}{ Cherukulangara temple pond } \\
\hline & $\begin{array}{l}\text { Surface } \\
\text { Water }\end{array}$ & Bottom water & Surface water & Bottom water & Surface water & Bottom water & Surface water & Bottom water \\
\hline Total solids & $1833.33 \pm 288.67$ & $2000 \pm 500$ & $833.33 \pm 288.67$ & $1000 \pm 0$ & $833.33 \pm 288.67$ & $1000 \pm 0$ & $1333.33 \pm 288.67$ & $1500 \pm 0$ \\
\hline $\mathrm{Ph}$ & $6.33 \pm 0.29$ & $6.5 \pm 0$ & $7.5 \pm 0.5$ & $7.66 \pm 0.29$ & $6.83 \pm 0.29$ & $7 \pm 0.5$ & $6.5 \pm 0$ & $6.5 \pm 0.5$ \\
\hline $\mathrm{DO}_{2}$ & $4.79 \pm 0.28$ & $4.51 \pm 0.28$ & $6.34 \pm 0.36$ & $5.92 \pm 0.28$ & $5.35 \pm 0.28$ & $5.07 \pm 0.28$ & $4.51 \pm 0.56$ & $4.47 \pm 0.36$ \\
\hline $\mathrm{DCo}_{2}$ & $6.16 \pm 0.35$ & $4.84 \pm 0.35$ & $3.81 \pm 0.25$ & $2.75 \pm 0.41$ & $3.96 \pm 0.44$ & $3.55 \pm 0.56$ & $7.92 \pm 0.35$ & $7.48 \pm 0$ \\
\hline Carbonate & Nil & Nil & Nil & Nil & Nil & Nil & Nil & Nil \\
\hline Bicarbonate & $6.66 \pm 2.88$ & $13.33 \pm 2.88$ & Nil & Nil & $5 \pm 0$ & $6.66 \pm 2.88$ & $15 \pm 5$ & $18.33 \pm 2.88$ \\
\hline Calcium & $18.33 \pm 2.88$ & $20 \pm 0$ & $8.33 \pm 2.88$ & $10 \pm 0$ & $13.33 \pm 2.88$ & $15 \pm 0$ & $21.66 \pm 2.88$ & $21.66 \pm 5.77$ \\
\hline Magnesium & $16.66 \pm 2.88$ & $16.66 \pm 5.773$ & $6.66 \pm 2.88$ & $8.33 \pm 2.88$ & $3.33 \pm 2.88$ & $5 \pm 0$ & $13.33 \pm 2.88$ & $15 \pm 0$ \\
\hline Chloride & $49.7 \pm 7.1$ & $54.43 \pm 4.91$ & $28.4 \pm 7.1$ & $33.13 \pm 4.09$ & $47.33 \pm 4.099$ & $49.7 \pm 7.1$ & $63.9 \pm 7.1$ & $68.63 \pm 4.099$ \\
\hline Sulphate & $79.68 \pm 0.783$ & $81.6 \pm 1.357$ & $72.96 \pm 0.783$ & $76.8 \pm 0.96$ & $67.2 \pm 1.752$ & $69.84 \pm 0.919$ & $60.72 \pm 1.639$ & $63.36 \pm 1.357$ \\
\hline Phosphate & $0.61 \pm 0.11$ & $0.66 \pm 0.12$ & $0.52 \pm 0.18$ & $0.56 \pm 0.13$ & $0.38 \pm 0.11$ & $0.42 \pm 0.05$ & $0.30 \pm 0.05$ & $0.36 \pm 0.20$ \\
\hline Nitrate & $35.5 \pm 0.55$ & $36.22 \pm 0.60$ & $30.25 \pm 1.25$ & $31.04 \pm 1.22$ & $22.20 \pm 1.50$ & $23.44 \pm 0.22$ & $18.80 \pm 1.20$ & $19.80 \pm 1.25$ \\
\hline
\end{tabular}


Table.4. Chemical parameters of Aryanambi temple pond during the study period Nov.2012-Feb.2013

\begin{tabular}{|c|c|c|c|c|c|c|c|c|}
\hline \multirow[b]{3}{*}{ Parameters } & \multicolumn{2}{|c|}{ Nov.2012 } & \multicolumn{2}{|c|}{ Dec.2012 } & \multicolumn{2}{|c|}{ Jan.2013 } & \multicolumn{2}{|c|}{ Feb.2013 } \\
\hline & \multicolumn{2}{|c|}{ Aryanambi temple pond } & \multicolumn{2}{|c|}{ Aryanambi temple pond } & \multicolumn{2}{|c|}{ Aryanambi temple pond } & \multicolumn{2}{|c|}{ Aryanambi temple pond } \\
\hline & $\begin{array}{l}\text { Surface } \\
\text { Water }\end{array}$ & Bottom water & Surface water & Bottom water & Surface water & Bottom water & Surface water & Bottom water \\
\hline Total solids & $2166.66 \pm 288.67$ & $2333.33 \pm 288.67$ & $1666.66 \pm 288.67$ & $2000 \pm 0$ & $1333.33 \pm 288.67$ & $1500 \pm 0$ & $1833.33 \pm 288.67$ & $2166.66 \pm 288.67$ \\
\hline $\mathrm{Ph}$ & $6.6 \pm 0.29$ & $6.83 \pm 0.29$ & $7.83 \pm 0.29$ & $8.0 \pm 0$ & $7.33 \pm 0.29$ & $7.5 \pm 0.5$ & $6.83 \pm 0.29$ & $7.0 \pm 0.5$ \\
\hline $\mathrm{Do}_{2}$ & $4.08 \pm 0.36$ & $3.94 \pm 0.28$ & $5.49 \pm 0.36$ & $5.07 \pm 0.28$ & $4.93 \pm 0.36$ & $4.79 \pm 0.28$ & $3.80 \pm 0.36$ & $3.66 \pm 0.28$ \\
\hline $\mathrm{DcO}_{2}$ & $12.43 \pm 0.22$ & $10.78 \pm 0.56$ & $6.60 \pm 0.44$ & $6.45 \pm 0.25$ & $8.80 \pm 0.44$ & $7.33 \pm 0.25$ & $14.41 \pm 0.75$ & $13.64 \pm 0.44$ \\
\hline Carbonate & Nil & Nil & Nil & Nil & Nil & Nil & Nil & Nil \\
\hline Bicarbonate & $13.33 \pm 2.88$ & $20 \pm 0$ & $5 \pm 5$ & $6.66 \pm 2.88$ & $10 \pm 0$ & $11.66 \pm 2.88$ & $21.66 \pm 2.88$ & $23.33 \pm 2.88$ \\
\hline Calcium & $20 \pm 5$ & $23.33 \pm 2.88$ & $11.66 \pm 2.88$ & $13.33 \pm 2.88$ & $15 \pm 0$ & $16.66 \pm 2.88$ & $25 \pm 0$ & $28.33 \pm 2.88$ \\
\hline Magnesium & $20 \pm 0$ & $23.33 \pm 2.88$ & $10 \pm 0$ & $11.66 \pm 2.88$ & $8.33 \pm 2.88$ & $10 \pm 0$ & $16.66 \pm 2.88$ & $21.66 \pm 5.773$ \\
\hline Chloride & $56.80 \pm 7.1$ & $59.16 \pm 8.198$ & $35.5 \pm 7.1$ & $40.23 \pm 4.099$ & $35.5 \pm 7.1$ & $42.6 \pm 7.1$ & $73.36 \pm 4.099$ & $85.2 \pm 7.1$ \\
\hline Sulphate & $95.76 \pm 0.919$ & $98.16 \pm 1.44$ & $90.0 \pm 0.919$ & $93.36 \pm 0.919$ & $85.44 \pm 0.783$ & $87.36 \pm 0.96$ & $74.4 \pm 0.554$ & $78.08 \pm 0.554$ \\
\hline Phosphate & $0.80 \pm 0.08$ & $0.84 \pm 0.15$ & $0.77 \pm 0.08$ & $0.79 \pm 0.13$ & $0.62 \pm 0.11$ & $0.65 \pm 0.12$ & $0.54 \pm 0.12$ & $0.58 \pm 0.16$ \\
\hline Nitrate & $36.12 \pm 1.02$ & $37.54 \pm 0.88$ & $34.0 \pm 0.50$ & $34.92 \pm 0.18$ & $25.55 \pm 0.15$ & $28.22 \pm 0.80$ & $20.40 \pm 0$ & $22.10 \pm 0.22$ \\
\hline
\end{tabular}

Fig.1.Showing Temperature variation in Pond A

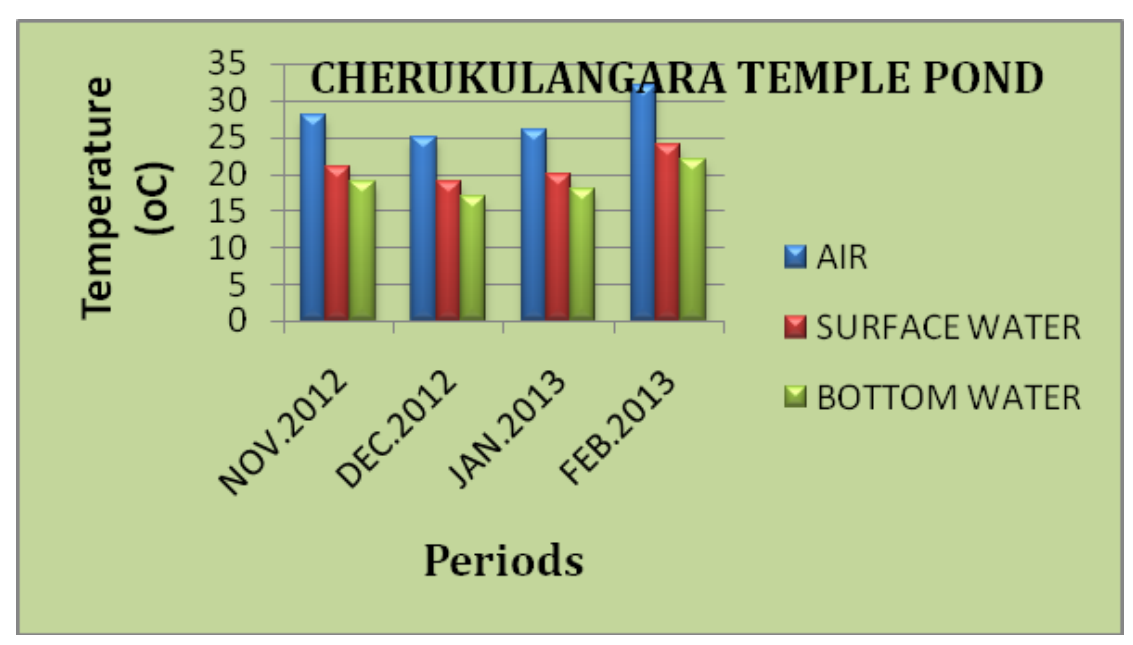

\section{Fig.2.Showing Temperature variation in Pond B}

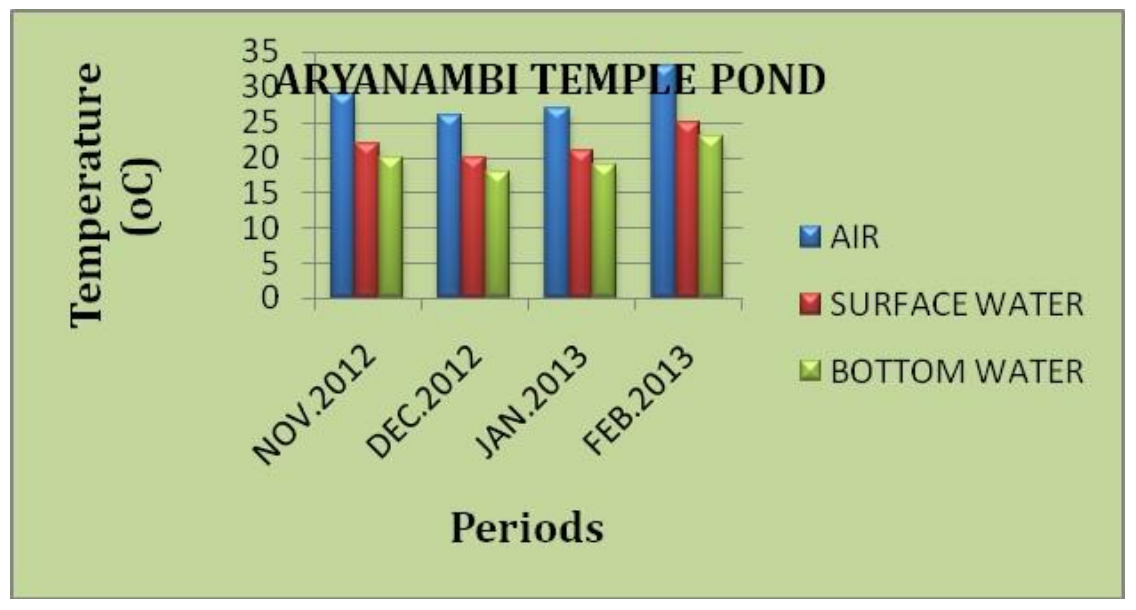


Fig.3.Showing Disssolved oxygen in Pond B

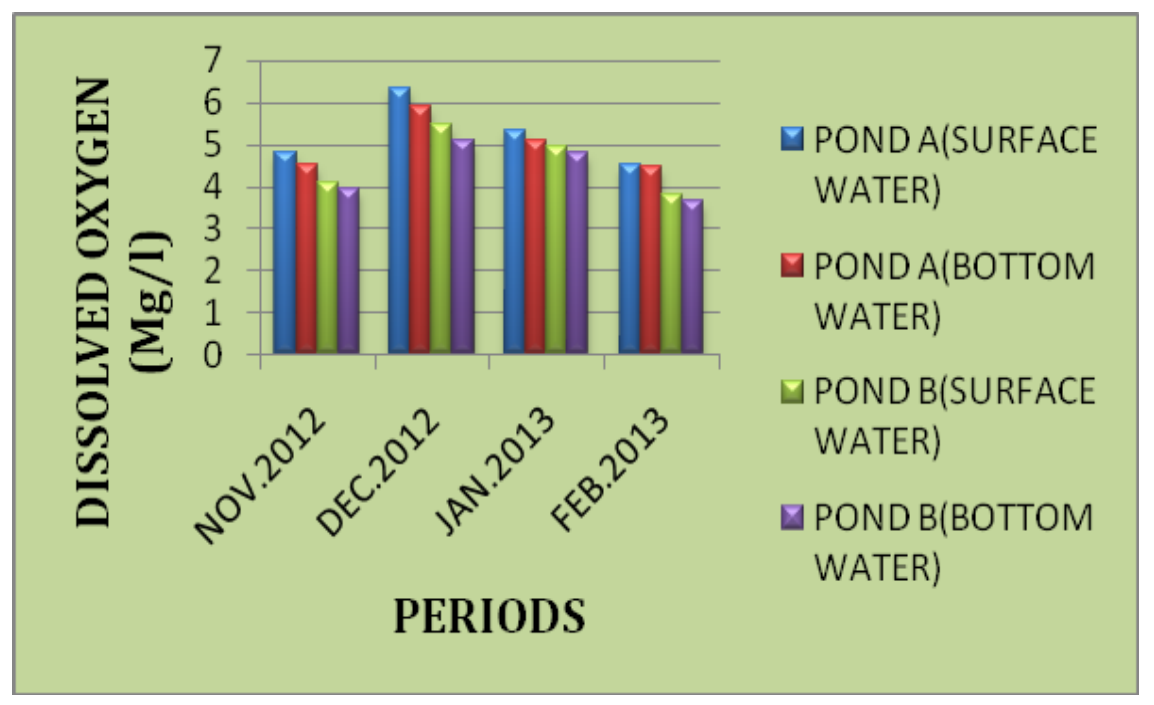

Fig.4.Total solids in Pond A and B

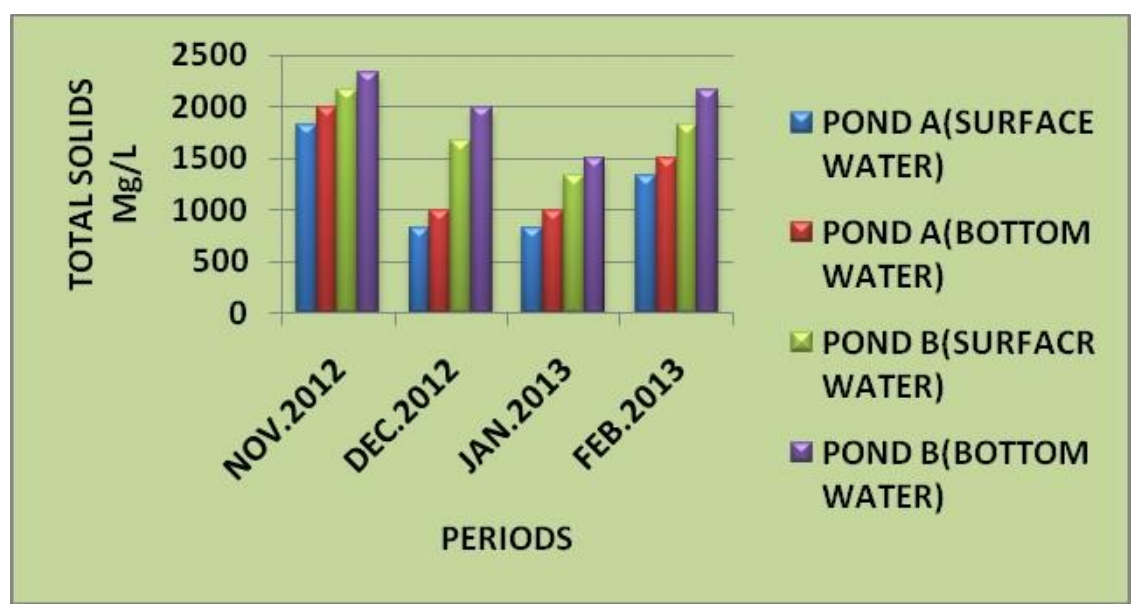

Fig.5. pH in Pond A and B

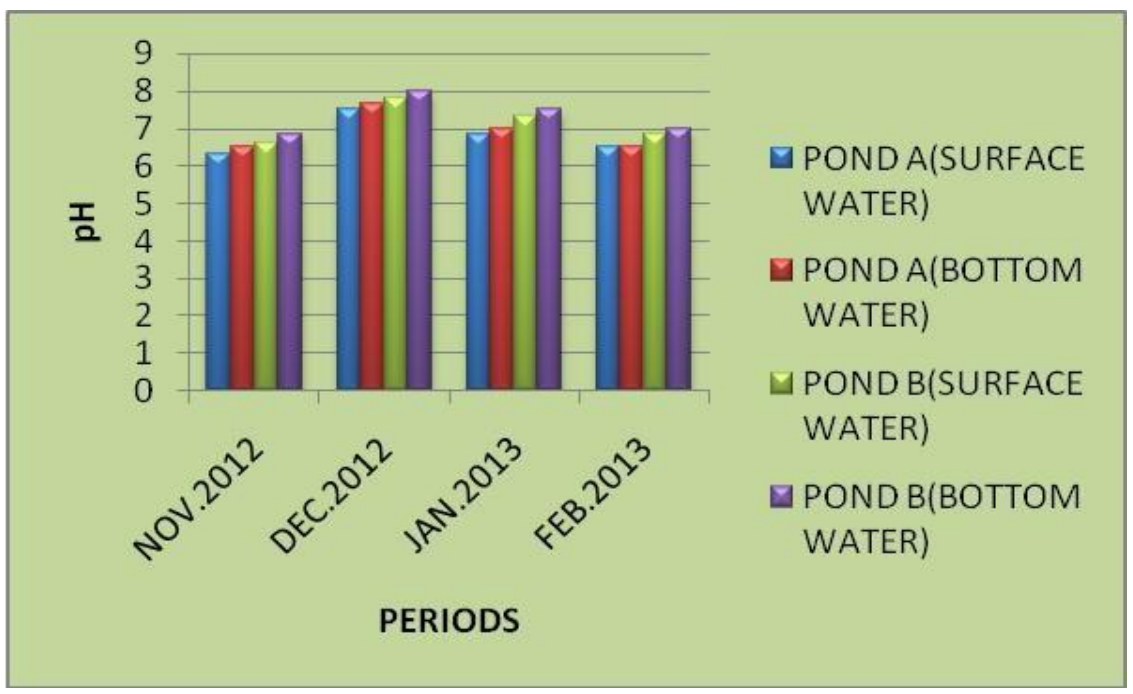

Fig.6.Dissolved carbondioxide in Pond A and B

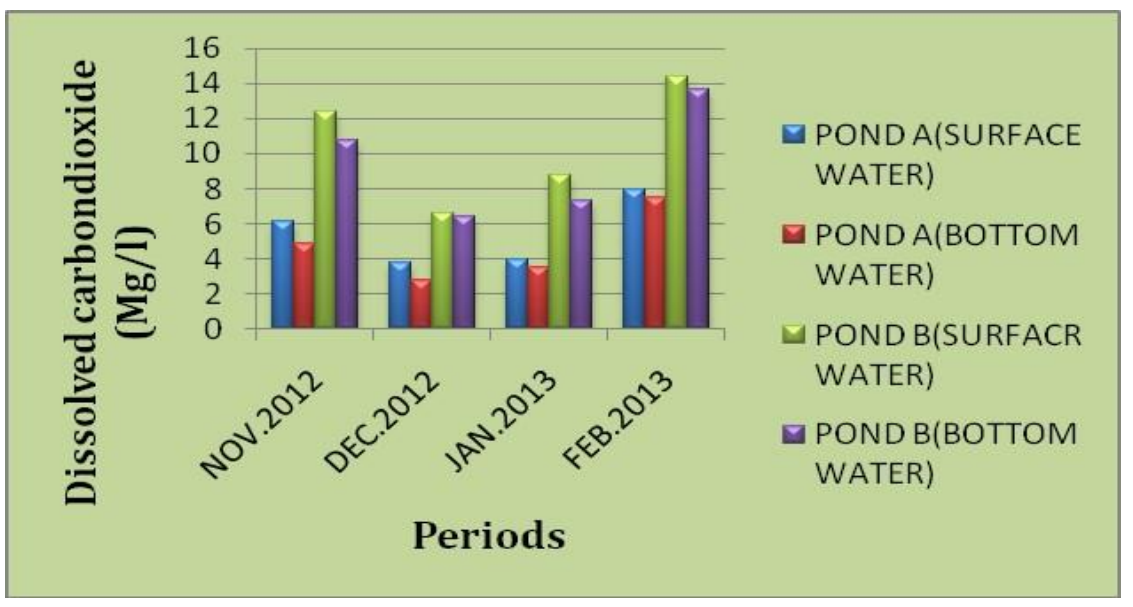


Fig.7.Bicarbonate in Pond A and B

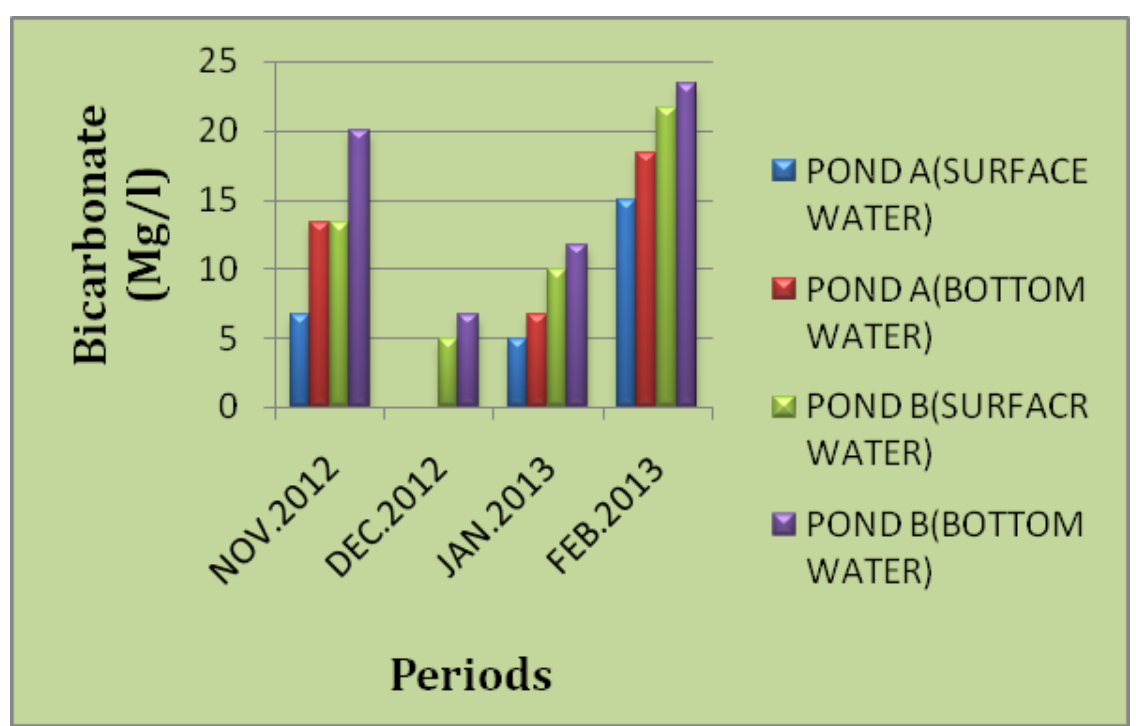

Fig.8.Calcium in Pond A and B

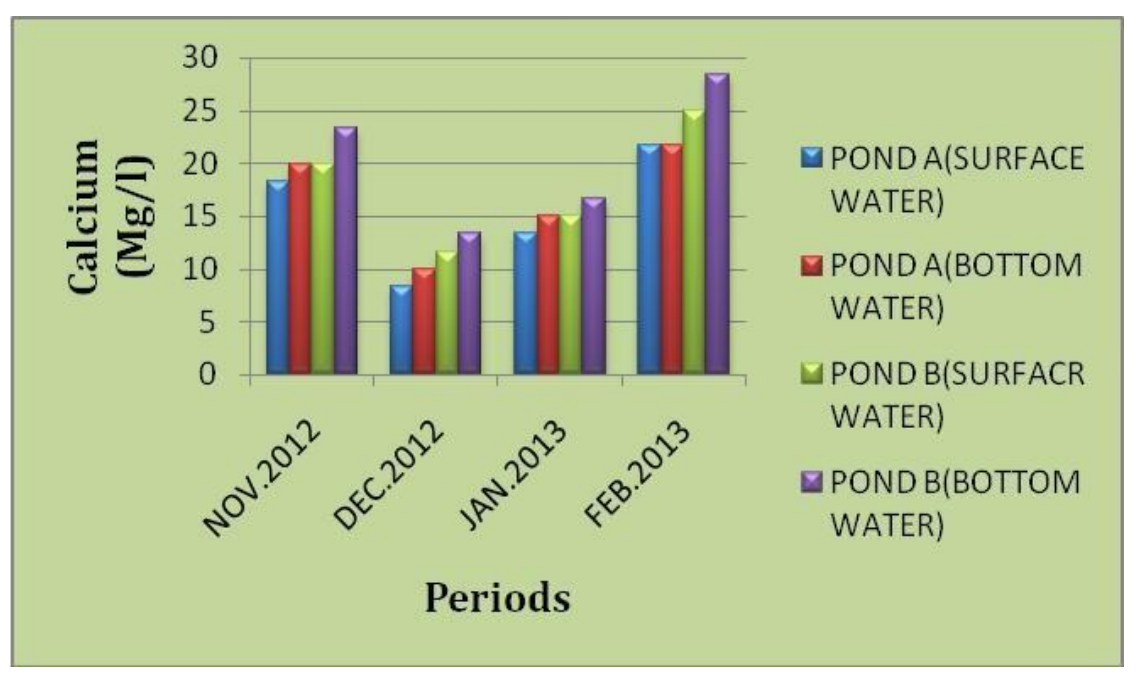

Fig. 9.Phosphate in Pond A and B

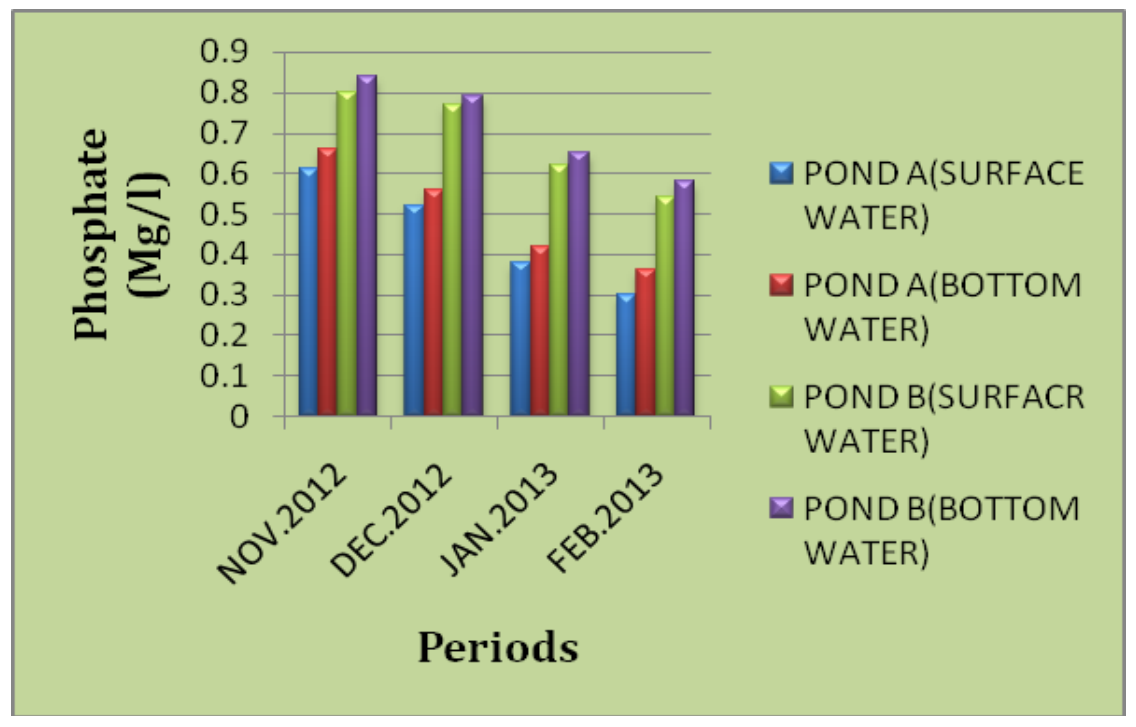

Fig.10.Magnesium in Pond A and B

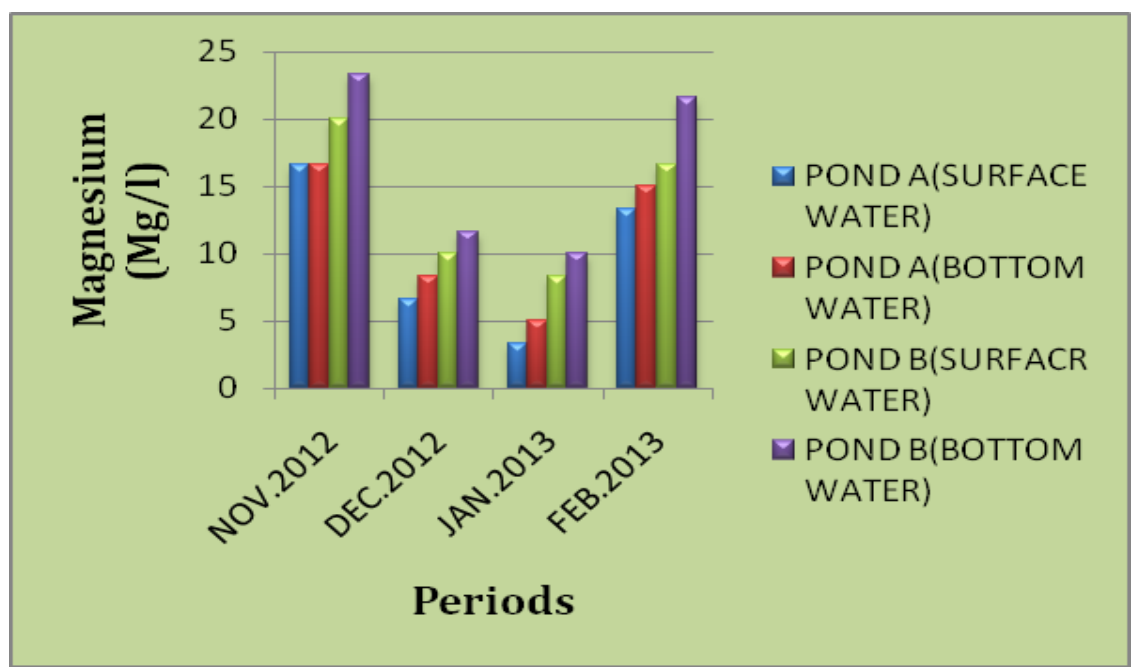


Fig.11.Chloride in Pond A and B

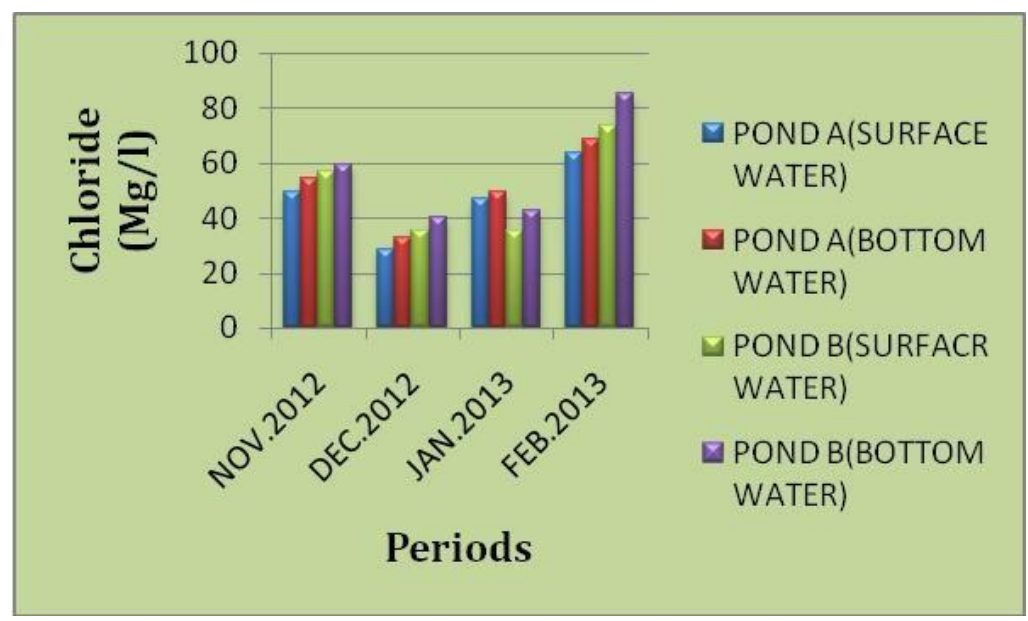

Fig.12.Sulphate in Pond A and B

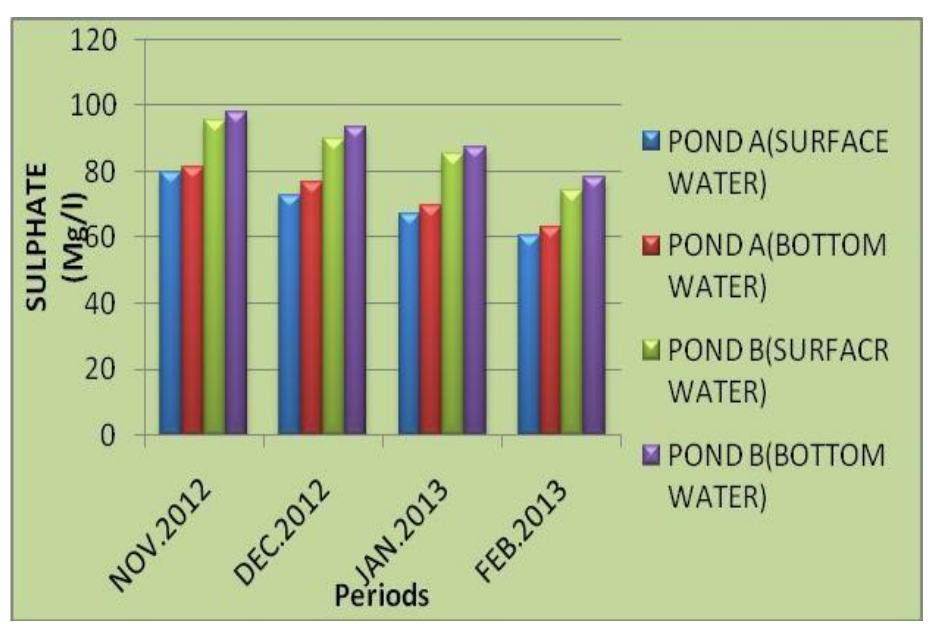

Fig.13.Nitrate in Pond A and B

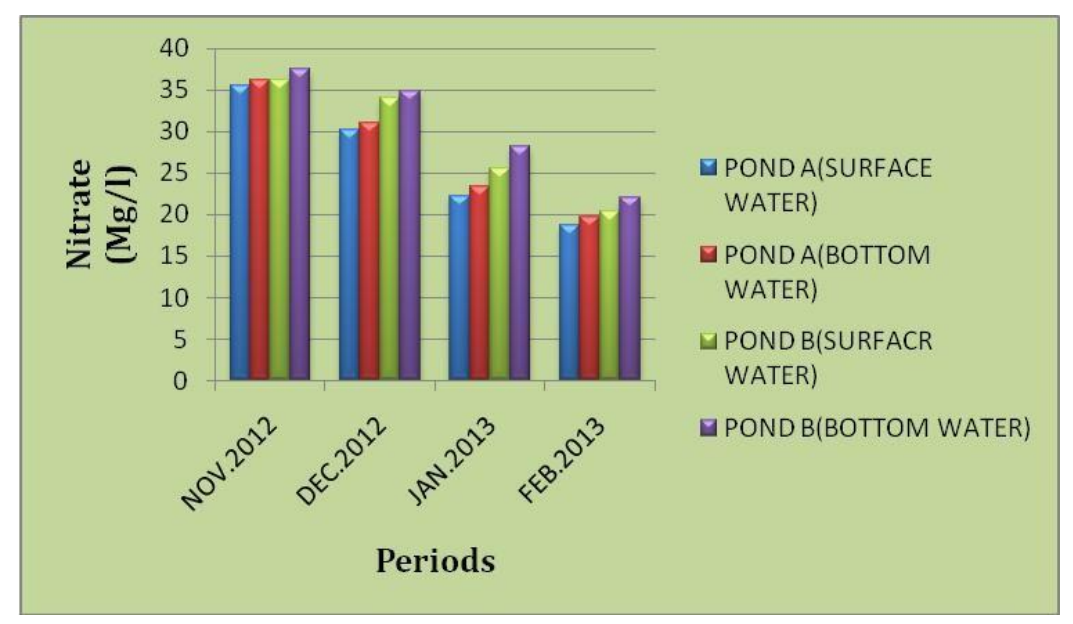

